\title{
From the Editor-in-Chief: New Projects and Partnerships
}

\author{
Svitlana (Lana) Krys
}

MacEwan University

$\mathbf{T}$

The current issue of East/West: Journal of Ukrainian Studies is a special thematic issue, titled "Empire, Colonialism, and Famine in the Nineteenth and Twentieth Centuries." Guest edited by Bohdan Klid of the Canadian Institute of Ukrainian Studies (CIUS) at the University of Alberta, the issue features eight articles and one translation of an article previously published in Ukrainian. Together, the contributors trace the links between imperial policies, colonial rule, and famines in the historical contexts of the Soviet Union under Stalinism, Nazi Germany and its allies during World War II, nineteenth- and twentieth-century British colonial rule in Ireland and Bengal, and Mao's Communist China. The issue is based on conferences held in Toronto and Kyiv. It inscribes the 1932-33 famine in Ukraine, known as the Holodomor, into a global conversation of not only state-induced famines but also famines that occur as a result of deliberate colonial policies. The issue also features an array of reviews and two review articles of recent titles in Ukrainian studies. Finally, the issue offers an obituary for Bohdan Medwidsky, the founder of the Kule Folklore Centre and the Bohdan Medwidsky Ukrainian Folklore Archives at the University of Alberta.

Future publications of EWJUS will include special sections on the Intermarium and security in the Black Sea region, co-planned with the Contemporary Ukraine Studies Program of the CIUS, and on early modern Ukraine, stemming from the 2019 conference of the Italian Association of Ukrainian Studies. EWJUS also has two fully thematic issues in the works that will be dedicated to (i) contemporary cultural responses to the ongoing war in Ukraine's east and (ii) the city of Odesa (a companion volume to EWJUS's recent issue on Kharkiv).

EWJUS continues to enjoy stable growth. Our readership statistics show a steady interest, thanks to our recently signed agreement with Coalition Publica-a partnership between the Public Knowledge Project and Érudit (a Canadian not-for-profit academic platform that provides publishing and dissemination services to Canadian scholarly journals). EWJUS's page on Érudit can be accessed at East/West - Érudit (erudit.org). Other databases that currently index EWJUS include the Directory of Open Access Journals, 
the MLA Directory of Periodicals, and EBSCO-partnered databasesAmerican Bibliography of Slavic and East European Studies, America: History and Life, EBSCOhost-Academic Search Complete, and Linguistic Bibliography/Bibliographie Linguistique. Such broad indexing provides EWJUS with better visibility and searchability. Indeed, since my last editorial report (September 2020), EWJUS's publications have been downloaded more than 19,000 times in over 100 countries.

In winter 2021, EWJUS launched another project-Ukrainian-English translation-that will make our publications more visible and available in the Ukrainian language. EWJUS has established academic co-operation with the MA translation program at the Taras Shevchenko National University of Kyiv. Through this co-operation, EWJUS will offer senior graduate students in the program internship opportunities for a capstone project in academic translation. The Ukrainian side of the project is headed by Prof. Lada Kolomiyets. Currently, articles from the most recent issue of EWJUS (vol. 7, no. 2, fall 2020) are being translated. Translation of four articles has been completed thus far, and translation of three other articles is expected to be finalized in spring 2021, with a goal to publish translations of all articles from vol. 7, no. 2 in the fall of 2021. A separate section on the EWJUS website will house all translations to highlight them, and translations will also appear alongside the original articles in the table of contents of relevant volumes.

This translation project has been two years in the making, and I am proud to have finally launched it. This is a unique opportunity to make EWJUS's Anglophone publications available in Ukrainian. I hope that Ukrainian translations of EWJUS publications will make an impact on scholarship in Ukraine, strengthen the dialogue between scholars in Ukraine and scholars in Anglophone countries, and increase EWJUS's international readership.

The publication of our current volume (vol. 8, no. 1, spring 2021) was made possible by the generous support of the Peter and Olya Savaryn Award Fund at the Canadian Foundation for Ukrainian Studies, for which I am grateful. I am also thankful to guest editor Bohdan Klid, to the Holodomor Research and Education Consortium, and to Liudmyla Hrynevych (Institute of the History of Ukraine, National Academy of Sciences of Ukraine) for their work on this issue, as well as to our book review editor Tania Stech (CIUS, Toronto Office), our two copyeditors, Marcia Craig (Edmonton, AB) and Ksenia Maryniak (CIUS), our editorial assistant Cossette Massa (MacEwan University), and Halyna Klid (CIUS) who designed the cover. The continuing COVID pandemic has disrupted work and lives. I hope that reading and reflecting on the latest research in our field can offer solace to our readers. An open access platform provides EWJUS issues to readers free of charge, so please share our publications with colleagues and interested parties!

April 12, 2021 